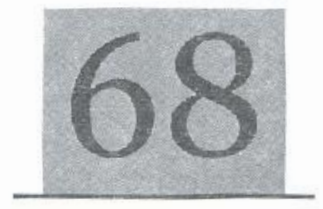

\title{
A comparative study of the decomposition of Rhizophora racemosa and Nypa firuticans of the Great Kwa River, Cross River State, Nigeria
}

\author{
Ama-Abasi, D. $/$ Umoren. I.
}

\begin{abstract}
Mangroves are specialized marine ecosystem which is highly productive. They act as shelter, breeding and nursery grounds for a variety of marine and brackish water invertebrates and fishes. Some of the dominant plant species in mangrove vegetation of Nigerian causttine are Rhizophora species and Nypa fruticans. Studies were conducted on the decamposition of Rhizophora species and N. fruticans. The objective was to compare their decomposition rates and proffer informed management decisions. Decomposition rates of the two species were monitored for 112 days using litter box experiment. Eight litter boxes were stocked with $20 \mathrm{~g}$ of leaves of each species and fortnightly two boxes containing the respective plants species were removed and examined for dry matter, carbon and nitrogen contents. There was no significant difference in the rates of decomposition of Rhizophora and $N$. fruticans leaves ( $p \geq 0$ () 05) even though $N$. fruticans showed slightly higher rate of decomposition than Rhizophora. The linear relatianship between the loss in dry matter and number of days were expressed as $Y=10.1-0.080 x$ in $N$. fruticans, and $Y-9.0-0.073 x$ in Rhizophora sp. It was concluded that the argument in favour of the eradication of $N$. fruticans for the thriving of Rhizophora is inaccurate. Containment of the population rather than control is the logical strategy for the management of the riparian vegetation in the face of climate change.
\end{abstract}

Keywards: Decomposition rates, Nipa palm, mangrove, ecosystem management.

Introduction

$\mathrm{M}$ angroves are specialized and highly productive marine ecosystem. They act as shelter, breeding, feeding and nursery grounds for a wide variety of marine and brackish water invertebrates and fishes. In the Nigerian coastline, the two dominant species of mangroves are Rhizophora spp and $N$. fruticuns. However in recent years, there has been an alarming deterioration in the population of Rhizophora. Various reasons advanced include the displacement of the native Rhizophora by the exotic $N$. fruticans. Holzochner and Nwosu (1997) observed that near settlement along the Cross River Estuary, there were more of $N$. fruticans than Rhizophora and farther away where there was no settlement, there was apparent peaceful coexistence between the two species. They therefore concluded that the disappearance of the Rhizophora species was more anthropogenic in origin than competition with $N$. fruticans. Some authors have argued that $N$. fruticans is not useful and should be eradicated in order to give room for the thriving of Rhizophora (Moses 1985). Most of these arguments do not have strong scientific evidence.

It was the objective of this study to compare the dry matter content, the carbon and nitrogen content of the two dominant species of mangrove and to compare their decomposition rates in order to proffer informed management decisions of the riparian vegetation.

\section{Materials and Methods}

Great Kwa River is a tributary of the Cross River Estuary taking its origin from the Oban Hills in Akamkpa Local government of Cross River State, Nigeria. Located between latitudes $4^{\prime \prime} 45^{\prime}$ and $5^{\circ} 15^{\prime} \mathrm{N}$ and longitudes $8^{\circ} 15^{\prime}$ and $8^{\circ} 30^{\prime} \mathrm{E}$, the river is 56 $\mathrm{km}$ long and $28 \mathrm{~km}$ wide at the mouth where it empties into the Cross River estuary. The description of the hydrology and the vegetation of the Area is given by Okorafor, et al. (2012). The decomposition rates of Rhizophora sp and $N$. fruticans were monitored through litter box experiment. Approximately $20 \mathrm{~g}$ of leaves of Rhizophora and $N$. fruticans were placed in boxes covered with netting material of about $1 \mathrm{~mm}$ mesh size. Eight of such boxes contained Rhizophora leaves and 8 contained Nypa leaves. The boxes were placed at the intertidal zone of the Great Kwa River tied to mangrove roots to avoid being washed away by tidal waters. Another sct of leaves with the same weight was oven- dried to constant to get the dry matter 
weight of the fresh leaves. The dry matter was weighed using sensitive electronic balance, model PM- 2000. The value of the dry matter was used as the starting point to monitor the decomposition of the leaves. At a fortnightly interval, a box containing the leaves of each of the species was removed and its contents washed to remove debris and mud particles. The decaycd leaves were oven- dried to constant weight and the dry matter, carbon and nitrogen contents were determined. The experiment was run for 112 days. Organic carbon contents of the leaves was ascertained using $2 \mathrm{~g}$ sample and by the dichromate wet oxidation method of Walkley and Black as outlined by Jackson (1969). The total nitrogen content of the leaves was determined using modified macro-Kjedahl method (Jackson, 1969).

\section{Results and Discussion}

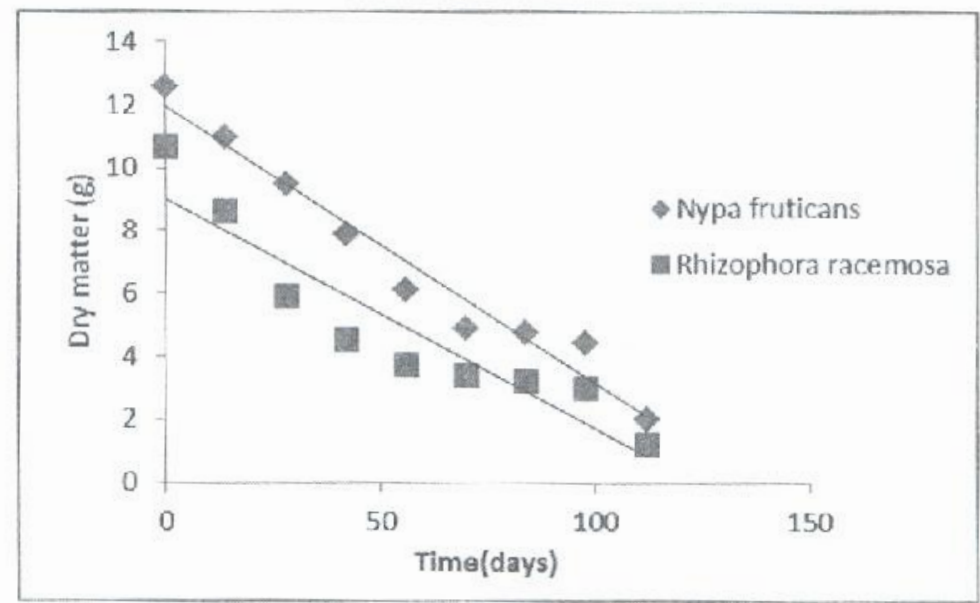

Fig. 1: Linear regression showing the rates of decomposition af two mangrove species Rhizophora $s p$.

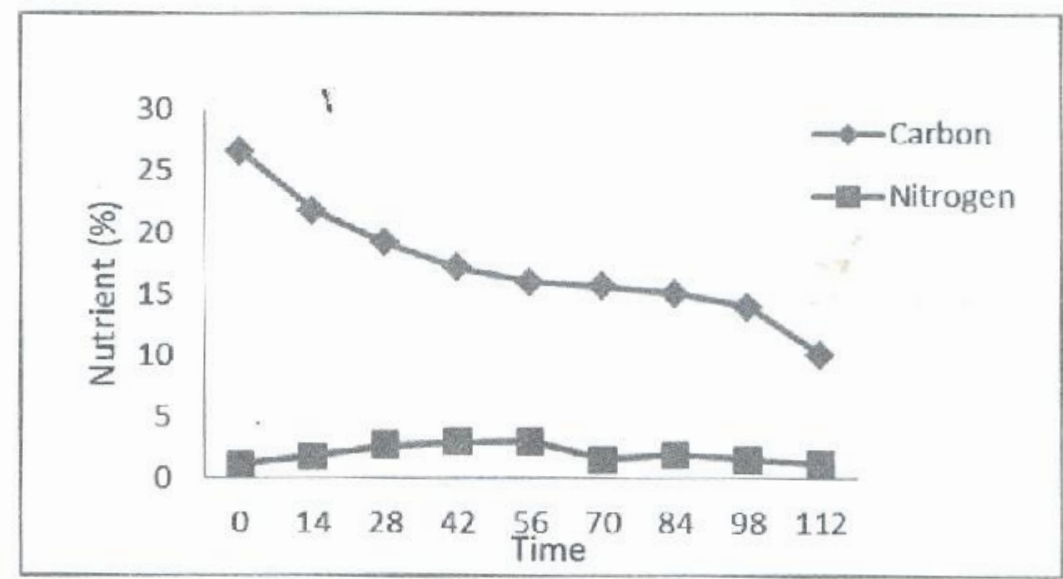

Fig. 2: Carbon and Nitrogen levels in decomposing leaves of $R$. racemosa.

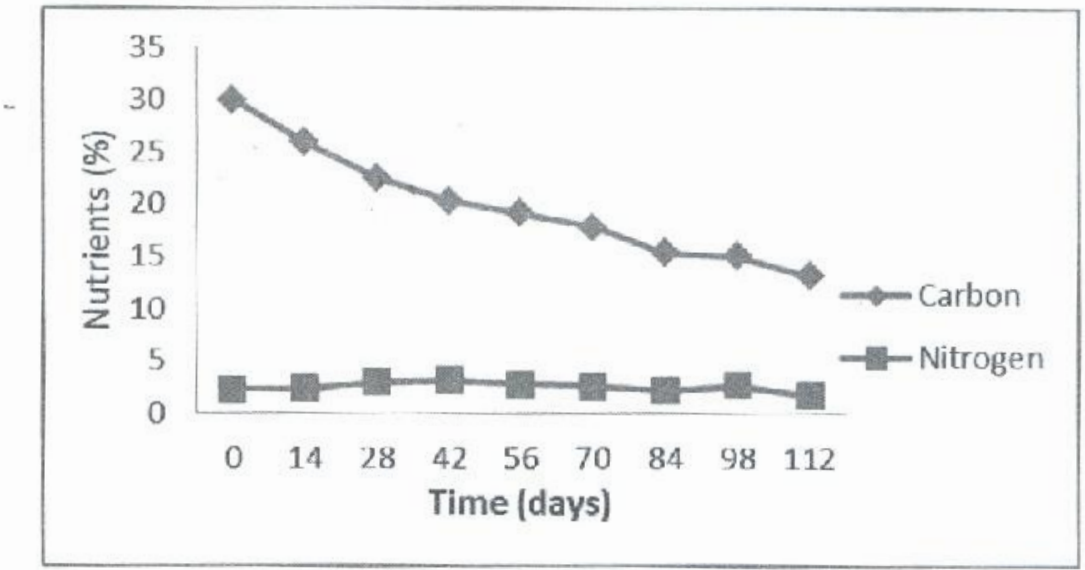

Fig. 3: Levels of carbon and nitrogen in decomposing leaves of $\mathrm{N}$. fruticans.

The initial dry matter weight of Rhizophora was $10.70 \mathrm{~g}$ while that of $N$. fruticans was $12.54 \mathrm{~g}$. The initial nitrogen was $2.26 \%$ and $1.12 \%$ for Nypa and Rhizophora respectively. The organic carbon was $29.99 \%$ and $26.62 \%$ for Nypa and Rhizophora respectively. Fig. 1 shows the linear regression between the number of days and the dry matter loss as the experiment 
progressed. The dry matter was getting reduced signifying that part had been lost to the sediment through decomposition. $\Lambda s$ seen by the graph, decomposition progressed at a faster rate at the onset of the experiment as shown by the steep slope of the regression line, but slowed down in Rhizophora after the first sixty days but in $N$. fruticans it slowed down twelve days later, before finally dropping sharply again at the end of the experiment. The earbon level followed the same pattern as the dry matter loss (Fig 2). However, the nitrogen level rose during the first 56 days in Rhizophora while in Nypa it rose the first 42 days before declining to steady level till the end of the experiments (Fig 3). The linear regression model between the number of days and the dry matter loss was expressed as, $Y=9.0-0.073 \mathrm{x}$, in Rhizophora and $\mathrm{Y}=10.1-0.088 \mathrm{x}$, in $N$. fruticans. $\Lambda$ student $\mathrm{t}$-test distribution revealed that there was no significant difference between the rates of decomposition of Rhizophora and $N$. fruticans cven though $N$. fruticans decomposed very slightly faster than Rhizophora ( $\mathrm{p} \geq 0.05, \mathrm{n}=8)$.

The fact that the dry matter, carbon and nitrogen contents per unit gram of fresh leaves of $N$. fruticans were higher than that of Rhizophora shows that Nypa is richer in nutrients and biomass than Rhizophora. The initial faster rate of decomposition is due to high density of decomposers particularly bacteria and fungi. The decrease in the rate of decomposition later in the course of the experiment is as a result of the reduction in the density of these decomposers. Rajendran and Kathiresan (2007) reported that density of decomposers are much from the early days of decomposition and thereafter declines. They observed that both bacteria and fungi decreased in density towards the end of their experiment. Thus our work confirmed that earlier observation. The initial increase in the level of nitrogen before the drop is as a result of nitrogen fixing bacteria that colonized the leaves before the final decay Shunula and Whittick, (1999) made a similar observation. Akpan-Idiok and Solomon (2012) listed four autochthonous bacteria responsible for the decomposition of leaf litter in the mangrove swamp soils of the Cross River estuary to include Pseudomonas sp, Micrococcus sp, Streptomyces sp and Bacillus sp.

Given the rate of decomposition and reduction in carbon and nitrogen in $N y p a$ compared to Rhizophora, Nypa is bound to contribute more to the fertilization of the sediment in the event of leaves litter. Therefore the assertion that Nipa palm is unproductive is incorrect. Udoidiong and Ekwu (2011) discovered that Nypa fruticans does not adversely affect epibenthic fatrin-species richness but, rather it increases species richness through habitat heterogeneity. It is the richness in dry matter and nutrient that probably attract many epibenthic fauna to $N$ fruticans as observed by Udoidiong and Ekwu (2011).

\section{Conclusion}

In conclusion the argument that Nypa palm should be eradicated because it is not beneficial to the ecosystem is inaccurate and lacks scientific proof. The containment of the Nypa population rather than control should be seen as the logical strategy in the management of the mangrove vegetation of the Great Kwa River and indeed other mangrove wetlands in the coastal communities of the country. This will enhance the conservation of the biodiversity of the coastal waters and check coastline erosion in the face of flooding oceasioned by climate change.

\section{REFERENCES}

Akpan-Idiok, A.U. and Solomon, M.G. (2012). Bacterial isolates of the mangrove swamp soils in the Cross River estuary, southeast Nigeria. Research Journal of Soil Biology, 4(2): 32-41.

IJolzloehner, S. and Nwosu, F.M. (1997). Nypa palut of the inner Cross River estuary: A survey. Trans. Nig. Soc Biol Conserv. 6:26 35 ,

Jackson, D.L. (1969). Effects of water, light and nutrition in flower bud initiation in apricols. Aust. J. Biol. Sc,. 22:69-75.

Moses, B.S (1985). The potential of mangrove swamp as a food producing system. Wilcnx, B. H. R. and Powell, C. B. (eds.). The Mangrove Ecosystem of the Niger Deita. Publications Committee, University of Port Harcourt. 170-184.

Okorafor, K.A., Andem, A.B., Okete, J.A. and Ettah, S. E. (2012). Composition, distribution and abundance of macro invertebrates in the shores of the Great Kwa River, Cross River State, southeast, Nigeria. European Journal of Zoological Research, 2: 31-36.

Rajendra, N. and Kathiresan, K. (2007). Microbial flora associated with submerged mangrove leaf litter in India. Rev: Biol. Trop (Int. J. Trop. Biol), 55(2): $393 \quad 400$

Udoidiong, O.M. and Ckwu, A. . . (2011). Nipa Palm (Nypa fruficans) and the intertidal cpibenthic macrofauna east of the Imo River Estuary, Nigeria. World Applied Sciences , foumal, 14/9: 1320-1330.

Shunula, J.P. and Whittick, A. (1999). A note on leaf litter degradation and nitrogen and carbon release in species from three families of mangroves in Zanzibar. WIOMSA Book Series, 1:227-232. 